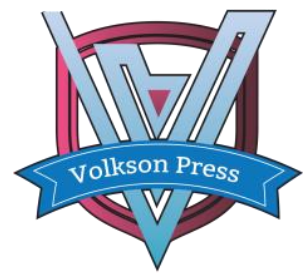

Contents List available at VOLKSON PRESS

Economics \& Management Innovations(EMI)

DOI : http://doi.org/10.26480/icemi.01.2017.177.179

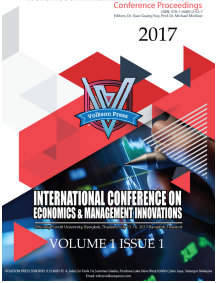

\title{
The Effects of RMB Exchange Rates Changes on the Automobile Import and Export Trades of China
}

\section{Rui Wang}

Accounting Department, School of Economics and Management, Nanjing University of Science and Technology Nanjing, Jiangsu Province, China 642525829@qq.com

This is an open access article distributed under the Creative Commons Attribution License, which permits unrestricted use, distribution, and reproduction in any medium, provided the original work is properly cited.

\section{ARTICLE DETAILS}

\section{Article History:}

Received 02 october 2017

Accepted 06 october 2017

Available online 11 october 2017

Keywords:

Fluctuations of exchange rates,

Auto export, Auto import.

\section{ABSTRACT}

The purpose of the paper focuses on analyzing the relationship between the fluctuations of exchange rates and auto imports and exports with data from 2006 to 2015. We find that short-term changes of RMB exchange rates do not have an evident association with auto foreign trades. However, in the long term, appreciation of RMB has a negative impact on auto exports and is positive related to auto imports, while the positive relation is not evident. Depreciation of RMB improves auto exports and deteriorates the auto imports although the relation is very weak and limited.

\section{Introduction}

With the deepening of the International division of labor and the extension of global industrial chain, the trade interactions between different countries are becoming increasingly frequent. Foreign trade is the main source of China's foreign currency revenue, which provides strong support for China's economic development and technological progress. The reform of exchange rate system in China has gone through three stages, from "dual rate system", "peg to the US dollars" to a managed floating exchange rate regime based on market supply and demand with reference to a basket of currencies.

The output value of automotive industry in China has gained a rapid development in recent years due to the prosperous economy. Auto industry achieve gross value of foreign trades 9.85 billion dollars, $0.0117 \%$ of the GDP in 1998. In 2015, the gross value reached 156.4 billion dollars, $0.2289 \%$ of the GDP. Our country's auto industry has entered a high growth stage and makes a great contribution to the whole economy along with the expansion of export market from developing countries to the developed ones.

2. The Present Situation of the Automobile Import and Export Trades of China

\subsection{Scales}

Since China has joined the WTO in 2001, the auto industry enters a high growth stage armed only with cheap labor, a potential consumptive market and constant supply of automotive products. In 2006-2015, the total value of auto import and export increase to 55897.8 million dollars from 10455.93 million dollars, and the average growth rate per annum is $43.46 \%$. In comparison with the surge in import, we cannot ignore the slowdown in export growth. As in Table 1, the volume of auto export is 11231.39 million dollars in 2015, which is away below the imports.

We can see from the Table 1, both the imports and exports exhibit a steady growth and wide trade gap. Especially after 2009, the deficit worsens year by year. China starts the reform of RMB exchange rate regime in 2005, our auto imports develop very fast, exceeding the exports. It implies that the auto industry has been influenced by the exchange rate changes and still has a long way to go to perfect technology, service and sales network in order to compete with other multinational car manufacturers on the market home and abroad.

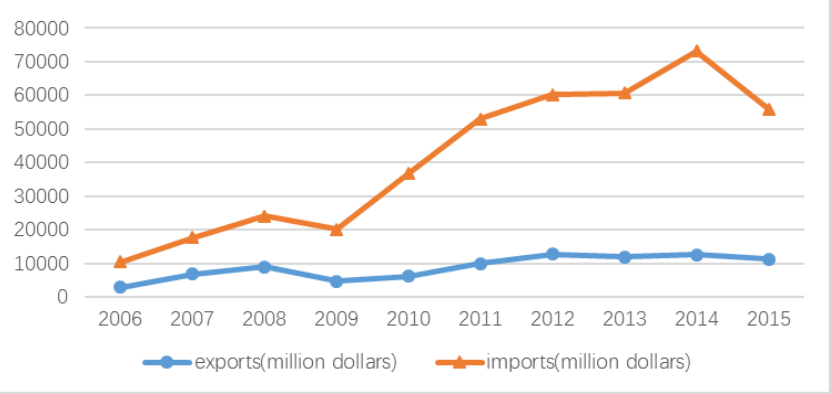

Table 1 Auto Imports and Exports in China

\subsection{Markets}

In 2003, the top 10 auto export countries are Russia, Chile, Algeria, Iran, Ukraine, Egypt, Colombia, Brazil, Uruguay and Iraq, 63.7, 46.7, 38.2, 34.0, $29.7,21.2,11.7,16.9,16.8$ and 16.8 thousand, respectively. The export volume to top 10 countries make up a share of $71 \%$. We can turn to more details in Table 2 .

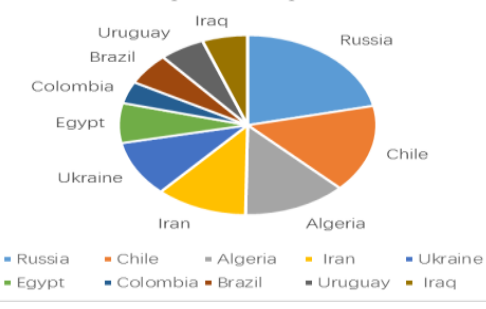

Table 2 Top 10 Auto Exports Countries

Germen is the top auto import country in China with a proportion of over 25\%, followed by Japan and England. But this ratio keeps reducing after 2005. The auto import from Germen is 177.8 thousand, decreased by 31.8 thousand compared to 2010. Imports from other top 10 countries fluctuate in a small range. In conclusion, auto import markets centralize in Germen, Japan and England, which indicates some irrationality.

3. The Analysis of Effects of RMB Exchange Rates Changes on the Automobile Import and Export Trade of China 
3.1 The Analysis based on the Elasticity Approach

Elasticity refers to the effect of the rate of change of a variable on the rate of change of another variable. This paper utilizes Real Effective Exchange Rate of RMB elasticity of auto import and export trades and the formula is $d y / y / d r / r . d y / y$ points to changes of auto import and export and $d r / r$ is fluctuations of RMB exchange rate. Usually, exchange rate is positively related to changes of import, negatively related to export. So the results can be classified as three cases:

(1) When $d y / y / d r / r=-1$, exchange rate changes is consistent to that of foreign trades;

(2) When $d y / y / d r / r<-1$, exchange rate changes is larger than that of foreign trades;

(3) When $d y / y / d r / r>-1$, exchange rate changes is smaller than that of foreign trades.

Table 3 Real Effective Exchange Rate of RMB elasticity of auto import and export trades

\begin{tabular}{|c|c|c|c|c|c|}
\hline & $\mathrm{X}_{\mathrm{t}}$ & $\mathrm{M}_{\mathrm{t}}$ & Er & $\begin{array}{ll}\quad & \left(X_{t}\right. \\
\left.X_{t+1}\right) /( & \text { Er- } \\
\left.E_{r+1}\right) & \\
\end{array}$ & \begin{tabular}{ll} 
& \multicolumn{1}{c}{$\mathrm{M}_{\mathrm{t}}$} \\
$\left.\mathrm{M}_{\mathrm{t}+1}\right) /($ & $\mathrm{Er}$ \\
$\left.\mathrm{E}_{\mathrm{r}+1}\right)$ & \\
\end{tabular} \\
\hline $\begin{array}{l}200 \\
6\end{array}$ & 2938.16 & 7517.77 & $\begin{array}{l}114.783084 \\
5\end{array}$ & $\begin{array}{l}- \\
28.5625333 \\
6\end{array}$ & $\begin{array}{l}- \\
9.73783844 \\
1\end{array}$ \\
\hline $\begin{array}{l}200 \\
7\end{array}$ & 6810.09 & $\begin{array}{l}10895.3 \\
6\end{array}$ & $\begin{array}{l}109.487264 \\
4\end{array}$ & $\begin{array}{l}- \\
3.50426694 \\
6\end{array}$ & $\begin{array}{l}- \\
4.48037325 \\
9\end{array}$ \\
\hline $\begin{array}{l}200 \\
8\end{array}$ & 8877.98 & $\begin{array}{l}15125.2 \\
9\end{array}$ & 100 & $\begin{array}{l}28.7746746 \\
8\end{array}$ & $\begin{array}{l}- \\
0.92908757 \\
4\end{array}$ \\
\hline $\begin{array}{l}200 \\
9\end{array}$ & 4681.05 & $\begin{array}{l}15356.1 \\
6\end{array}$ & $\begin{array}{l}98.3571150 \\
9\end{array}$ & $\begin{array}{l}- \\
35.9305174 \\
7\end{array}$ & $\begin{array}{l}- \\
110.140168 \\
7\end{array}$ \\
\hline $\begin{array}{l}201 \\
0\end{array}$ & 6195.3 & $\begin{array}{l}30583.3 \\
3\end{array}$ & $\begin{array}{l}97.4715986 \\
8\end{array}$ & $\begin{array}{l}- \\
13.1630515 \\
1\end{array}$ & -8.91156246 \\
\hline $\begin{array}{l}201 \\
1\end{array}$ & 9938.16 & $\begin{array}{l}43092.3 \\
5\end{array}$ & $\begin{array}{l}92.9979409 \\
9\end{array}$ & $\begin{array}{l}- \\
12.1392066 \\
4\end{array}$ & $\begin{array}{l}- \\
4.50335687 \\
6\end{array}$ \\
\hline $\begin{array}{l}201 \\
2\end{array}$ & $\begin{array}{l}12670.8 \\
4\end{array}$ & $\begin{array}{l}47488.0 \\
6\end{array}$ & $\begin{array}{l}90.8914198 \\
5\end{array}$ & $\begin{array}{l}2.90495953 \\
3\end{array}$ & $\begin{array}{l}- \\
1.36909309 \\
9\end{array}$ \\
\hline $\begin{array}{l}201 \\
3\end{array}$ & 11975.2 & $\begin{array}{l}48716.7 \\
9\end{array}$ & $\begin{array}{l}89.1736620 \\
1\end{array}$ & $\begin{array}{l}- \\
5.63129115 \\
6\end{array}$ & $\begin{array}{l}30.0498029 \\
1\end{array}$ \\
\hline $\begin{array}{l}201 \\
4\end{array}$ & $\begin{array}{l}12523.9 \\
9\end{array}$ & $\begin{array}{l}60630.1 \\
9\end{array}$ & 88.4479705 & $\begin{array}{l}- \\
7.40651744\end{array}$ & $\begin{array}{l}- \\
18.8946745\end{array}$ \\
\hline $\begin{array}{l}201 \\
5\end{array}$ & $\begin{array}{l}11231.3 \\
9\end{array}$ & $\begin{array}{l}44666.4 \\
1\end{array}$ & $\begin{array}{l}89.6804941 \\
6\end{array}$ & ---- & ---- \\
\hline
\end{tabular}

Note: Data are from China Association of Automobile Manufactures and National Bureau of Statistics of China from 2006 to 2015. The base year is 2008 and the index is 100.

In Table 3, 8 years in 2006-2014 excluding 2008, values of elasticity of auto import are smaller than -1 , about 88.9 percent. The result indicates that fluctuation of RMB exchange rate has a great impact on the auto import trades. Similarly, there are 7 values of elasticity of auto export below -1 , which take up $77.8 \%$. In a conclusion, there are 9 years ,except 2008, during which auto imports and exports are sensitive to RMB exchange rate changes. Although RMB exchange rate changes is not the determining factor that affects the auto foreign trades, but it does have an evident impact we cannot ignore.

\subsection{The Analysis in Terms of Absolute Magnitude}

With the rapid development of Chinese economy and implementation of opening and reform policy, Chinese auto makers emerge on the global market and play an important role. Apart from that, auto foreign trade balance has much to do with GDP and RMB exchange rate fluctuation. Since floating exchange rate regime is carried out in 2005, a flexible RMB exchange rate system begins to develop and improve driven by the market. As we know, 2008 financial crisis has a great impact the global economy. Influenced by the American government, RMB enters a period of appreciation. Recently, fluctuations of RMB become more frequent due to some financial institutions uncertain intentions and behavior. So we divide this ten years (2006-2015) into 2 parts, 2006-2008 and 2009-2015 as in Table 4 and Table 5.
From Table 4, we can clearly find that Real Effective Exchange Rate of RMB keeps decreasing with an average ratio of 1.45 annum. Comparing to 7.39 in 2006-2008, the speed of depreciation of RMB has decreased much more than expectations. But auto import does not seem to be affected by it because average increase ratio is 109.17 thousand dollars annum. The growth cannot exist without rapid development of the background economy so auto import and export. Consumers' demand drive the rise of production as well as the amount of export and import.

Table 4 changes of RMB exchange rate before 2009 (unit: million dollars)

\begin{tabular}{lllll}
\hline & Auto export & Auto import & & Real Effective Exchange Rate of RMB \\
\hline 2006 & 2938.16 & 7517.77 & & 114.7830845 \\
2007 & 6810.09 & 10895.36 & 109.4872644 \\
2008 & 8877.98 & 15125.29 & 100 \\
\hline
\end{tabular}

Table 5 changes of RMB exchange rate after 2009

(unit: million dollars)

\begin{tabular}{llll}
\hline & Auto export & Auto import & Real Effective Exchange Rate of RMB \\
\hline 2009 & 4681.05 & 15356.16 & 98.35711509 \\
2010 & 6195.3 & 30583.33 & 97.47159868 \\
2011 & 9938.16 & 43092.35 & 92.99794099 \\
2012 & 12670.84 & 47488.06 & 90.89141985 \\
2013 & 11975.2 & 48716.79 & 89.17366201 \\
2014 & 12523.99 & 60630.19 & 88.44797051 \\
2015 & 11231.39 & 44666.41 & 89.68049416 \\
\hline
\end{tabular}

3.3 The Analysis in Terms of Relative Magnitude

Table 6 Year-on-year growth of auto export

\begin{tabular}{lllll}
\hline time & $\begin{array}{l}\text { Real Effective Exchange Rate of } \\
\text { RMB }\end{array}$ & $\begin{array}{l}\text { year-on-year } \\
\text { export }\end{array}$ & growth of auto \\
\hline 2006 & -3.166261105 & 1034.88 & & \\
2007 & -5.295820075 & 3871.93 & & \\
2008 & -9.487264402 & 2067.89 & & \\
2009 & -1.642884912 & -4196.93 & & \\
2010 & -0.885516407 & 1514.25 & & \\
2011 & -4.473657687 & 3742.86 & & \\
2012 & -2.106521144 & 2732.68 & & \\
2013 & -1.717757844 & -695.64 & & \\
2014 & -0.725691495 & 548.79 & & \\
2015 & 1.23252365 & -1292.6 & & \\
\hline
\end{tabular}

Year-on-year growth is calculated by data in current year and last year, the formula is $Y=X_{i} / X_{i-1}, X_{i}$ is data in year $i$ and $X_{i-1}$ is data in year $i-1$.

Comparing the measure in the term of absolute magnitude, it is easier to see the changes during each year. In 2006-2015, there are only 3 years negative year-on-year growth, which is approximately consistent to the depreciation of RMB. It indicates that exchange rate changes do not impact auto foreign trades. But in 2009, depreciation of RMB is not serious but export amount falls down a lot due to financial crisis that leads to the decrease of demand on overseas market. In 2010-2012, auto industry begin to recover from the crisis in spite of the pressure of forcing RMB to appreciate. However, this improvement does not maintain for long. Yearon-year growth becomes negative again for the shadow of European debt crisis. Appreciation of RMB in 2015 makes the situation worse than before. Overall, it is not evident to observe the positive association between depreciation of RMB and auto export improvement but appreciation of RMB indeed has a negative impact, especially during some big events, like financial crisis.

Table 7 Year-on-year growth of auto import

\begin{tabular}{lll}
\hline time & $\begin{array}{l}\text { Real Effective Exchange Rate of } \\
\text { RMB }\end{array}$ & $\begin{array}{l}\text { year-on-year growth of auto } \\
\text { import }\end{array}$ \\
\hline 2006 & -3.166261105 & 2404.08 \\
2007 & -5.295820075 & 3377.59 \\
2008 & -9.487264402 & 4229.93 \\
2009 & -1.642884912 & 230.87 \\
Table & & \\
7. con & & \\
2010 & -0.885516407 & 15227.17 \\
2011 & -4.473657687 & 12509.02 \\
2012 & -2.106521144 & 4395.71 \\
2013 & -1.717757844 & 1228.73 \\
2014 & -0.725691495 & 11913.4 \\
2015 & 1.23252365 & -15963.78 \\
\hline
\end{tabular}

Form long term, appreciation of RMB stimulates auto import surge. In addition, decrease of auto price is an irreversible trend. So appreciation of $\mathrm{RMB}$ directly results in the prosperity of auto imports and vice versa. 
Interestingly, similar to export, exchange rate changes does not have a strong relation with year-on-year growth even against the expectations. It implies the limited impact of exchange rate on auto foreign trades.

\section{Conclusion}

This paper analyzes the relationship between the fluctuations of exchange rates and auto imports and exports with data from 2006 to 2015. We find that short-term changes of RMB exchange rates do not have an evident association with auto foreign trades. However, in the long term, appreciation of RMB has a negative impact on auto exports and is positive related to auto imports, while the positive relation is not evident. Depreciation of RMB improves auto exports and deteriorates the auto imports although the relation is very weak and limited. In conclusion, auto makers should transform uncertainty of exchange rate changes into advantages. Moreover, other sectors in the production should be taken into consideration in order to work out an alternative plan to ensure the constant operation of auto industry.

\section{References}

[1] Frankel and Wei, Assessing China's Exchange Rate Regime Economic Policy, CEPR, CES, MSH, vol. 22, pages 575-627, 07
[2] Stephen Roach. On the Next Asia: Opportunities and Challenges for a New Globalization[M] · America : Wiley,2009: 89-100

[3] Marquez J. Schindler J W. Exchange rate effects on China's trade: An interim report [R] - Board of Governors of the Federal Reserve System International Finance Discussion Paper, 2006, No. 861

[4] Boyd, Deriekand Ca Porale, Gugielmo Mariaand Smith Ron. Real Exchange Rate Effects on the Balance of trade: Co-integration and the Marshall-Lamer Condition. International Journal of Finance and Economics. 2001(6) : 14-20

[5] Christopher Fawson. Information Flows Among Exchange Rate Markets: What Do We Learn From Non—Deliverable Forward Markets [A] - China Finance

[6] Bahnani Oskooee M. Co-integration Approach to Estimate the Long-run Trade Elasticities in LCDs[J] - International Economics Journal, 1998, 12(3): 89-96 .

[7] Wilson , Peter - Exchange Rates and the Trade Balance : Korean Experience 1970 to 1996[J] - Seoul Journal of Economic , 2000(2) : 135-163 . 